\title{
Los espacios de religiosidad y la devoción femenina en la nobleza moder- na. El ejemplo de los linajes Aranda e Híjar ${ }^{1}$
}

\author{
Laura Malo Barranco ${ }^{2}$
}

Recibido: 1 de marzo de 2016 / Aceptado: 21 de diciembre de 2016

Resumen. A lo largo de la Edad Moderna, las mujeres de la nobleza desarrollaron su fe en distintos espacios religiosos. De forma privada, desde niñas aprendieron de las obras artísticas religiosas que adornaban las estancias de la casa y escucharon misa junto a sus damas en pequeños oratorios y capillas ubicados dentro del hogar. Al mismo tiempo, dichas damas formaron parte también de las prácticas religiosas compartidas por el conjunto de la sociedad. Algunas de ellas fueron educadas en conventos que las vieron tomar los votos y elegir la religión como forma de vida; otras, destinadas al matrimonio, vivieron su devoción junto al resto de los fieles, en parroquias, ermitas y cofradías. Su fe quedó vinculada a cultos y espacios del linaje, cuyo patrimonio otorgaba a la mujer la posibilidad de ejercer un patronazgo religioso y vivir su fe de un modo privilegiado.

Palabras clave: mujer; nobleza; devoción; oratorio; prácticas religiosas; patronazgo femenino.

\section{[en] Devotional Spaces and Noble Women's Religiosity in Early Modern Spain Aranda and Híjar Lineages}

\begin{abstract}
In Early Modern Spain, noble women developed their faith in different religious spaces. Privately, since they were little girls, they learned from the religious pieces of art that adorned their houses' rooms and listened the holy mass next to their ladies-in-waiting in little oratories and chapels placed inside noble family homes. At the same time, noble women were part too of the religious practices shared with the complete society of this period. Some of them were educated in convents that saw them later taking vows and choosing religion as their way of life; another ones, destined to marriage, lived their devotion together with the common of the people in parishes and brotherhoods. Their faith was linked to their lineage's cults and proprieties, whose wealth gave women the possibility of becoming religious patrons and live their faith in a privileged way.
\end{abstract}

Keywords: Woman; Nobility; Devotion; Oratory; Religious Practices; Feminine Patronage.

Sumario. 1. Introducción. 2. El interior del hogar y los espacios privados de religiosidad. 3. La religiosidad en el exterior. Educación, profesión, culto y patronazgo. 4. Conclusiones.

\footnotetext{
1 Este trabajo se realiza vinculado al Proyecto de Investigación HAR2014-52434-C5-2-P, "Elites políticas y religiosas, sacralidad territorial y hagiografía en la Iglesia hispánica de la Edad Moderna" con Eliseo Serrano Martín como investigador principal, y al Grupo de Investigación Consolidado Blancas de la Universidad de Zaragoza.

$2 \quad$ Universidad de Zaragoza 1malo@unizar.es
} 
Cómo citar: Malo Barranco, L. (2017) Los espacios de religiosidad y la devoción femenina en la nobleza moderna. El ejemplo de los linajes Aranda e Híjar, en Cuadernos de Historia Moderna 42.1, 175-193.

\section{Introducción}

Las mujeres de la alta nobleza en la Edad Moderna compartían con el conjunto social una relación muy estrecha con los espacios religiosos. La casa, la iglesia y el convento eran lugares en los que no sólo se desarrollaban las prácticas devocionales, sino donde, además, se constituían para ellas entornos de formación, relación y patronazgo.

Debido a la privilegiada situación de las damas nobles, sus vínculos con los ambientes religiosos poseían características especiales. En el interior y exterior del hogar su relación con los espacios de religión quedaba marcada por la especificidad de su posición e influía de forma directa en la creación de sus devociones particulares. Su elevado status en el orden social y su gran capacidad económica favorecían la posibilidad de transformar el interior doméstico en un ambiente fuertemente influenciado por la religión, gracias al arte que lo decoraba y a aquellas estancias ideadas especialmente para el desarrollo del culto. Fuera de los muros de la casa, las mujeres de la nobleza gozaban de toda una serie de ventajas en el acceso a instituciones religiosas y aprovechaban su preeminencia para ejercer gran cantidad de acciones piadosas y fundacionales relativas a los lugares de culto.

Las siguientes líneas buscan presentar la relación existente a lo largo de la modernidad entre los espacios dedicados a la práctica religiosa y las devociones femeninas en el mundo nobiliario. Para ello, el estudio se centrará en los casos referentes a las damas nobles pertenecientes a los linajes Aranda e Híjar, dos destacadas familias de la sociedad moderna española. Dirigido por la historiografía reciente relativa a la religiosidad femenina y sus prácticas durante la Edad Moderna, este trabajo plantea un análisis de partidas de bautismo y confirmación, actas matrimoniales, testamentos, codicilos e inventarios de bienes, que permiten un acercamiento a las devociones particulares de las mujeres nobles. Influido por los estudios de élite, género, religiosidad y vida cotidiana el texto siguiente trata de establecer los vínculos entre los espacios vitales y la obtención y desarrollo de devociones personales, a través de la influencia de la religión plasmada en el día a día de las damas de la nobleza.

\section{El interior del hogar y los espacios privados de religiosidad}

El inicio de la Edad Moderna, con la llegada del siglo XVI, estuvo marcado por la adopción de nuevas formas de experiencia religiosa que se desarrollaron a lo largo de dicho periodo histórico. La influencia del humanismo y de la llamada devotio moderna, así como de las ideas que marcaban el camino hacia "la "piedad reflexiva' de Erasmo de Rotterdam y la nueva espiritualidad de los místicos españoles"3, fomentaron una vivencia más personal de la religión y sus prácticas. Las mujeres

Urquízar Herrera, A: Coleccionismo y nobleza. Signos de distinción social en la Andalucía del Renacimiento, Madrid, Marcial Pons, 2007, pp. 78-79. 
de la nobleza, educadas e inmersas en los círculos humanistas a los que pertenecían muchos de sus esposos y familiares, hicieron suyas también estas nuevas directrices religiosas que vinculaban la experiencia de la fe a un universo más íntimo, el cual necesitaba de espacios propios para la oración y la meditación.

El interior del hogar ofrecía la posibilidad de crear un escenario propicio para la práctica religiosa que fomentara dicha reflexión individual. De este modo, las familias privilegiadas introdujeron dentro de sus casas y palacios gran cantidad de elementos decorativos de marcado carácter religioso. La imágenes relacionadas con los pasajes más destacados de las enseñanzas de la fe eran protagonistas de los programas decorativos en gran parte de las estancias de la casa noble. De este modo, la mirada de sus habitantes debía pasar cada día por prestar atención a aquellos personajes que como esculturas, como pinceladas en lienzos o tejidos en tapices compartían con ellos el espacio del hogar. Estas figuras eran concebidas como algo más que un simple elemento decorativo. A parte de su función material, que proporcionaba belleza a los diversos salones y cámaras de la casa a la vez que exponía el poder adquisitivo de sus propietarios; las decoraciones religiosas "fueron también creadas para enseñar, inspirar y confortar"4 siendo utilizadas por los habitantes del hogar noble de modo individual y colectivo, como complemento indispensable en las prácticas religiosas cotidianas.

El transcurso del día a día en un ambiente fuertemente marcado por la presencia de dichas representaciones tenía obviamente una influencia en la percepción del conjunto familiar en relación con el mundo religioso. El sentimiento producido por dichas figuras referentes a la doctrina católica poseía una doble dirección. Por un lado, enmarcaba la devoción particular de quienes las aportaban y ubicaban en la residencia familiar. Por otro, producía un efecto moralizante y devoto en quienes las observaban y relacionaban las figuras con el ejemplo religioso a seguir y con la protección familiar de los santos vinculada a los antepasados del linaje.

Una de las funciones destacadas que cumplían este tipo de elementos devoto-decorativos dentro del espacio del hogar estaba relacionada con la vertiente educativa de la imagen. Como responsables de la crianza y educación religiosa de sus hijos, las mujeres de la nobleza se responsabilizaron de la primera formación de sus descendientes a lo largo de la Edad Moderna. Tempranas maestras de los más pequeños de la casa y ejemplo principal en la formación e instrucción de las niñas, las mujeres nobles utilizaban las obras de arte existentes en sus residencias como ilustraciones que apoyaban sus lecciones. En ciertos casos, éstas eran adquiridas o encargadas -tanto por los varones como por las damas-, con el fin de que apoyaran el aprendizaje de los niños y niñas de la familia, siendo las mujeres del linaje principales responsables del uso de dichas imágenes.

La primera regla es tener imágenes de niños santos o de jóvenes vírgenes en la casa, en las cuales tus hijos, todavía en pañales, puedan deleitarse y a través de ellas alegrarse por medio de actos y canciones acordes a la niñez. [...] Deja a los niños verse reflejados en san Juan Bautista vestido con piel de camello, un niño pequeño que entra en el desierto, juega con los pájaros chupa la miel de las flores y duerme

Nalle, S. T.: "Private devotion, personal space. Religious images in domestic context" en De Carlos Varona, $\mathrm{M}^{\mathrm{a}}$. C. y otros (eds.): La imagen religiosa en la Monarquía hispánica. Usos y espacios, Madrid, Casa de Velázquez, 2008, p. 256. 
en el suelo. [...] Es deseable criar a las pequeñas niñas con la contemplación de las once mil Vírgenes y su discurso de rezo y sufrimiento. Deberían ver a santa Inés con su pequeño cordero. A santa Cecilia coronada con rosas, santa Isabel con flores en su regazo, santa Catalina y su rueca con otras representaciones que le ofreciesen con su primera leche el amor por la virginidad, por Cristo, el odio hacia el pecado.

Las representaciones de arte sacro perpetuaban entre los muros del hogar la diferenciación de los sexos presente en la realidad social y educativa. Además, ofrecían a las mujeres un reflejo del ideal femenino imperante, el cual quedaba plasmado en las piezas artísticas que completaban la decoración de la vivienda. Al mismo tiempo, cumplían su función como imágenes devotas y "situadas en dormitorios y, menos comúnmente, en capillas privadas, estos objetos visuales de devoción fueron frecuentemente el foco de las atentas miradas femeninas"6. Tal y como expresa doña Luisa María de Padilla (1591-1646), esposa del V conde de Aranda, en su obra Nobleza Virtuosa (1637) era importante que niños y niñas "desde muy chiquitos aprendan a reverenciar las imágenes (que han de tenerlas muy hermosas en sus aposentos)""7. Por medio de sus palabras, la condesa pretendía aconsejar a su hija sobre el modo en el que desarrollar la educación de sus descendientes. Entre aquellos consejos maternos puede leerse como doña Luisa sugería que

en el cuarto donde vuestros hijos se criaren, sería muy importante tener colgados algunos cuadros hechos de propósito, donde los vicios estén pintados horribles, las virtudes hermosas: porque así desde luego las amen y a ellos aborrezcan; que las opiniones aprendidas en la niñez son las que duran toda la vida ${ }^{8}$.

Estas palabras destacan la importancia de la posibilidad de educar a través de las imágenes. Éstas debían ser explicadas a los más pequeños de la casa de forma que pudiesen comprender su significado mientras escuchaban un relato que, además, los mantenía entretenidos ${ }^{9}$. En ambientes femeninos muchas de dichas pinturas, esculturas y tapices tenían una iconografía que representaba figuras de mujeres bíblicas, santas o de la antigüedad clásica, las cuales se encontraban entre las imágenes cotidianas que compartían espacios con las damas dentro de la casa. La observación, el aprendizaje y lo habitual de compartir lugares vitales con lienzos y tallas de mujeres ejemplares hacía que las damas nobles tuvieran muy presentes cuáles eran las virtudes que debían imitar. A las citadas representaciones femeninas se unía la destacada presencia de las imágenes de la Virgen dentro de los hogares de la nobleza. Ésta aparecía bajo sus múltiples advocaciones que favorecían la asimilación de las actitudes adoptadas por María, "reflejo de los ideales culturales de la condición femenina, tanto para el celibato como para la maternidad"10.

Dominici, G.: Regola del governo di cura familiare (1403), Firenze, Angiolo Garinei Libraio, 1860, p. 131.

6 Crum, R. J.: "Controlling women or women controlled? Suggestions for gender roles and visual culture in the Italian Renaissance Palace", en ReIss, S. E. y Wilkins, D. G.: Beyond Isabella. Secular women patron of arts in Renaissance Italy, Kirksville, Trumena State University Press, 2001, p. 42.

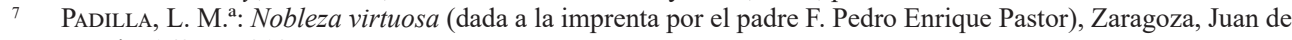
Lanaja, 1637, p. 313.

$8 \quad$ Ibidem, pp. 313-314.

9 "Para lo cual hará mucho el caso irles declarando lo que verán en la pintura, con que los entretendrán enseñándoles", Ibidem, p. 314.

10 KIng, M. L. y RabIL Jr, A. (eds.): Teaching other voices. Women and religion in Early Modern Europe, Chicago, 
Dentro de esta categoría de imágenes, en las que se entremezclaba la piedad religiosa con la educación femenina, podrían mencionarse varias obras que poseía en la segunda mitad del siglo XVII custodiadas en su guardarropa ${ }^{11}$, doña Mariana Pignatelli y Aragón, esposa de don Jaime de Silva Fernández de Híjar, V duque de Híjar. Entre ellas se describen obras cuyas protagonistas son mujeres insignes del Antiguo Testamento: "un quadro de Judith" o "cinco paños de la tapicería de la Reyna Ester". Y, además, aparecen también mencionadas mujeres mitológicas y de la antigüedad clásica que sugerían ideales de comportamiento femenino. En este caso destacan "ocho paños de la tapicería de Diana"12 y "un quadro de Lucrecia"13. A estas obras se unía la existencia de "otro quadro pequeño en tabla de una Abadesa", posiblemente una religiosa perteneciente a la familia, que se sumaría al ejemplo de voluntad piadosa necesariamente impreso en la realidad diaria femenina de la modernidad. Estas piezas artísticas se encontraban acompañadas por pinturas de la Virgen y de María Magdalena, esta última, modelo ideal de la mujer penitente, de la posibilidad de reforma de la mujer pecadora. Al mismo tiempo, junto a ellas, aparecían otras tablas y tapices que representaban rostros e historias con protagonistas masculinos. La Historia de Jacob, la Pasión de Cristo o los retratos de san Ignacio de Loyola, guardados entre las posesiones de la dama, permiten plantear que la búsqueda de la ejemplaridad femenina no debe reducirse únicamente a las figuras de mujeres, sino que para conocer su religiosidad es necesario a la vez plantear la también existente devoción por modelos masculinos.

En el interior del hogar, la habitación propia debía constituir también un espacio de práctica religiosa personal, donde nadie estorbara a la dama y ésta pudiese retirarse a orar "puesta de rodillas delante de la imagen de su Creador"14. Esta posibilidad de encontrar un lugar de retiro dentro de la casa, quedaba marcada por la situación social de las familias privilegiadas en las que a pesar de encontrarse unos límites muy laxos entre lo público y lo privado dentro del hogar, podían crearse ciertos espacios o elegir tiempos de relativa intimidad. Como ocurría en el resto de la residencia noble, la cámara femenina se encontraba también decorada con gran cantidad de imágenes de temática religiosa entre las que solía destacar el protagonismo de la Virgen María, el cual se repetía y solía representarse en lienzos de un tamaño mayor que los de otras figuras santas. Representaciones de Nuestra Señora de la Concepción o de la Leche ${ }^{15}$ aparecían dentro de las estancias personales de las damas nobles, en referencia a la devoción y protección buscada en relación con la importantísima tarea que desempeñaban en el conjunto familiar, pues ellas debían dar un heredero al linaje.

The University of Chicago Press, 2007, p. 38.

11 Inventario de los bienes realizado tras la muerte de Mariana Pignatelli y Aragón, esposa del V duque de Híjar, Jaime Francisco de Silva Fernández de Híjar, Zaragoza, 3 de junio de 1681, Archivo Histórico Provincial de Zaragoza, Casa Ducal de Híjar, (AHPZ, CDH), P/001510/000015.

12 Diana, diosa cazadora, es una referencia frecuente como modelo de castidad. Véase ANDERson, J.: "Rewriting the story of art patronage" en Women Patrons of Renaissance Art, 1300-1600, Renaissance Studies. Journal of the Society for Renaissance Studies, 10-2 (1996), p. 137.

13 "Heroína romana y ejemplo de virtud femenina en la Europa medieval y moderna.[...] esta mujer que eligió la muerte al deshonor, a pesar de su inocencia, sirvió muy bien a una cultura que premiaba la castidad femenina por encima de cualquier otro atributo". Véase SChUlER, C. M.: "Virtous Model/Voluptuous Martyr. The suicide of Lucretia in Northern Renaissance Art and its relationship to Late Medieval Devotional Imagery", en CARroLL, J. L. y Stewart, A. G. (eds.): Saints, sinners and sisters. Gender and Northern Art in Medieval and Early Modern Europe, Aldershot, Ashgate, 2003, p. 7.

14 Vives, J. L.: Instrucción de la mujer cristiana (1523), trad. Juan Justiniano (Valencia, 1528), introducción, revisión y anotación de E. T. Howe, Madrid, Universidad Pontificia de Salamanca, 1995, p. 118.

15 Las representaciones de la Virgen de la Leche fueron limitadas por el Concilio de Trento (1563) para evitar las imágenes del desnudo femenino. 
Junto a estas imágenes se describen, en ocasiones, elementos artísticos que permiten plantear la posible veneración personal e individual hacia una serie de figuras santas definidas que aparecen ubicadas en los espacios más privados de la mujer noble. De este modo, a la devoción del "Niño Jesús ${ }^{16}$ que tengo en la cabecera de mi cama"17, según decía la condesa doña Juana Rocafull en 1726, pueden unirse las estampas y cuadritos inventariados en las casas de doña Prudenciana Portocarrero, duquesa viuda de Híjar, tras su fallecimiento en 1764. Éstas últimas permiten buscar una relación entre la situación personal de la dama y las figuras que representaban su religiosidad en un momento determinado. Viuda desde 1749 y con 68 años de edad, habiendo perdido ya cuatro de sus cinco hijos, la duquesa doña Prudenciana poseía cerca de su tocador estampas de papel de Nuestra Señora de la Soledad y de los Afligidos y un cuadro pequeño en tabla de Jesús Nazareno. A ellos se unían "un quadrito de madera esttampa de papel de santa Polonia"18 y seis estampas finas de san Emigdio, patrones contra la enfermedad, quizás señal de los dolores propios de una dama de edad avanzada.

La preparación de una atmósfera determinada para el ejercicio personal de la fe dentro del hogar estaba, a la vez, fuertemente influenciada por las compañías elegidas para el desarrollo de la actividad cotidiana en las habitaciones femeninas. Las redes de relaciones sociales y familiares contribuían a la formación de los grupos de mujeres que compartían los espacios más íntimos de la dama noble. Ésta se encontraba rodeada por parientes y mujeres pertenecientes a una nobleza de menor titulación pero próxima al linaje, así como por sirvientas y criadas. La elección de dicha compañía era responsabilidad de la propia dama quien, respetando los compromisos de su padre o esposo, escogía con el objetivo de crear su círculo de amistad y compañía, el cual la definía en sus intereses, aspiraciones y prácticas religiosas. Caracterizados fundamentalmente por la personalidad de la mujer noble, es posible encontrar ciertos testimonios de la religiosidad individual en las prácticas cotidianas llevadas a cabo por estos grupos de mujeres. Un bello ejemplo es el descrito por Juan Lorenzo Merenzi y Aldaya en la Genealogía de los Ximénez de Urrea, dedicada en vida a la citada condesa de Aranda, doña Luisa María de Padilla (1591-1646). En ella, Merenzi y Aldaya alababa la gran religiosidad de doña Luisa, hecho justificado en parte por las características de elección y la actividad diaria de las damas, dueñas y criadas de la condesa.

Para admitir alguna en su servicio, además de la limpieza de sangre ha de tener tan grande en las costumbres que aventaje o ygual a la de las recoxidas religiosas; nunca tan grande escrutinio se haze para entrar en una religión estrecha como esta

16 "En muchos casos, estas pequeñas figuras formaban parte de los ajuares nupciales, contexto en el que la imagen del Niño Jesús resultaba una clara referencia al deseo de fecundidad de los esposos [...] En el ámbito doméstico, la imagen del Niño Jesús también participó en algunos aspectos de la vida familiar. Se encontraba ubicada en diferentes estancias de la vivienda [...] muy especialmente en las alcobas, y, por supuesto, en los oratorios privados, espacios destinados fundamentalmente al desarrollo de la religiosidad doméstica". Véase GARCíA SANZ, A.: "Análisis de una devoción doméstica: la imagen del niño Jesús en diferentes ámbitos de la vida cotidiana”, en Franco Rubio, G. (ed.): La vida de cada día. Rituales, costumbres y rutinas cotidianas en la España Moderna, Almudayna, Madrid, 2012, pp. 234-235.

17 Testamento de Juana de Rocafull y Rocabertí, esposa del VII conde de Aranda, don Dionisio Ximénez de Urrea, Zaragoza, 9 de septiembre de 1726. Archivo Histórico de Protocolos Notariales de Zaragoza (AHPNZ), Protocolo 5.372, ff. 451r.-455v.

18 Inventario de los bienes de Prudenciana Portocarrero, viuda del VII duque de Híjar, Isidro Fadrique de Silva Fernández de Híjar, Zaragoza y Villamayor, del 9 a 12 de junio de 1764. AHPZ, CDH, P/1-357-31. 
Santisima Señora, Phenix en virtud y prudencia, exercita para admitir una criada en su servicio, no tanto retiro y clausura se halla en ningún combento como sus criadas tienen en su quarto cada dia. A hora determinada se recoxen en un oratorio devoto, a donde después de media hora de lección espiritual, tienen otro tanto tiempo de oración mental. Está una criada dedicada para que a la ora de ella las comboque con el son de una campanilla y una Dama, y con ella una criada que le sirve para el attavio y compostura de una riquísima capilla, sirven las dos de Sachristanas ayudando de la limpieça del altar y de mudar los ornamentos con la variedad de los colores que el ceremonial trae según de los tiempos. [...] en esta Capilla les dicen misa sus dos capellanes y sin ser vistas sus Damas, aun del mismo que la dize, la oyen devotamente de una tribuna que guarnezida de espesas celosías tienen sin salir de su Quarto; de ocho a ocho días comulgan en ella y allí celebran las festividades de sus santos con tanta música, aparato, veneración y culto que en ninguna parte con mayor lo hacen ${ }^{19}$.

Sin abandonar todavía el interior del hogar noble, es necesario expresar la importancia en la devoción personal y familiar de determinadas estancias de la casa creadas específicamente para llevar a cabo la práctica devota, las cuales completaban la atmósfera doméstica de religiosidad. La presencia de oratorios y capillas fue una constante en las residencias nobiliarias durante toda la Edad Moderna. Estos espacios "suministraban un 'color de devoción' que sustentaba perfectamente la consideración de la piedad como categoría social, obtenida a través de la ligazón entre la posesión de oratorios y la pertenencia al estamento privilegiado" 20 . La posibilidad de escuchar misa en el interior de la propia casa, suponía una línea más de diferenciación entre el común de la sociedad y las clases privilegiadas. La "eficacia simbólica" que traían consigo dichos lugares privados de culto, al alcance de muy pocos, se hallaba unida a la posibilidad de construir espacios adecuados donde poder celebrar la eucaristía dentro de la casa. Para ello era necesaria la obtención de una licencia episcopal que solía ser sencilla de conseguir para las familias nobles, las cuales vivían estrechamente vinculadas a la jerarquía eclesiástica.

Estos espacios domésticos de culto eran estancias neutras utilizadas tanto por los hombres, como por las mujeres de la casa. En múltiples ocasiones recaía sobre la figura paterna la tarea de organización del oratorio o capilla, siendo el cabeza de familia responsable de la corrección en las prácticas religiosas llevadas a cabo dentro de su hogar.

Para evitar cualquier escándalo, sobre todo cuando las familias son numerosas, haciendo que todos, hombres y mujeres, se encuentren juntos en el oratorio siendo que pueden estar separados; me parecería mejor que el padre de familia recitara sus plegarias con los hombres y la madre con las mujeres en tiempos distintos. Si por el pequeño número de familiares, o por otra razón, pareciese bien al padre de familia que todos se encontraran presentes en el mismo lugar de oración, que tenga al menos la cautela de que haya siempre luz en el oratorio; y de colocarse aparte, donde cómodamente pueda ver todo aquello que hace cada uno ${ }^{21}$.

\footnotetext{
19 Merenzi y Aldaya, J. L.: Historia manuscrita de la Ilustre Casa y Familia de Ximénez de Urrea. AHPZ, CDH, $\mathrm{P} / 4-38-1.1625$

20 Urquízar Herrera, op. cit. (nota 3), p. 85.

21 Antoniano, S.: Dell'educazione cristiana e politica de figliuoli (1583), Milán, Giuseppe Pogliani, 1821, libro
} 
A pesar de este protagonismo masculino, las mujeres compartían las tareas de disposición y arreglo de dichas estancias con sus esposo. En ciertos casos, como en el mencionado a través del ejemplo relativo a las damas y sirvientas de la condesa de Aranda doña Luisa de Padilla, eran las mujeres las primeras encargadas de adornar y preparar la capilla en la que posteriormente oirían misa. Ellas podían constituirse como "sacristanas particulares [...] de oratorios y altares que existían en el espacio doméstico y cuyo cuidado estaba en manos de la mujer"22, la cual dedicaba parte de sus labores y tareas de manos a decorar y embellecer los espacios de culto dentro del hogar. La división antes citada que presenta la posibilidad de un uso del espacio de culto diferenciado por sexos, podía convertirse en una realidad cuando la residencia nobiliaria poseía dos espacios específicamente construidos para la práctica religiosa. En ocasiones, la documentación referente a las casas nobles alude a la existencia diferenciada de una capilla y un oratorio, o bien de un oratorio grande y otro pequeño. Dichos casos, podrían ofrecer a la dama principal de la casa la posibilidad de identificar como propio uno de los dos espacios, del que ser administradora y organizadora plena. Es interesante, a su vez, destacar el modo en que las damas, a lo largo de toda la modernidad, hacían referencia a algunos de estos espacios, que denominaban "suyos", aún en vida de sus esposos ${ }^{23}$.

El aprecio por dichas habitaciones, centro de la religiosidad doméstica, quedaba expresado en el deseo de conservación de los bienes custodiados en ellas, los cuales solían legarse en testamento o incluirse en mayorazgo familiar. "Quan justo es conservar los bienes y cossas que nuestros padres estimaban tanto, como son el oratorio y las reliquias e Ymagenes que dentro del ay"24. Con estas palabras iniciaba don Pedro de Urrea y Enríquez $(† 1607)$ la descripción de los bienes de su propiedad relativos al oratorio de su casa; unos bienes que le habían sido legados en el testamento de su madre ${ }^{25}$, doña Juana Enríquez y Cabrera $(† 1599)$, esposa del III conde de Aranda. Su recuento muestra una capilla y un oratorio pequeño en los que se habían reunido todos los objetos necesarios para llevar a cabo correctamente la práctica religiosa. Ejemplo de las descripciones de este tipo de habitaciones en las casas nobles durante la Edad Moderna, no faltaban en la capilla los elementos materiales para la celebración de la eucaristía: "una casulla con su estola, manipulo, alba y cordón de tafetán carmesí" y "un misal con su almohadilla y tabla de consagración guarnecida de plata", además del "cáliz y una patena sobredorada" o "las vinagreras de plata blancas de dezir missa". El altar mayor adornado con "un Christo crucificado grande de vulto" se encontraba acompañado por numerosos retablos, cuadros y reliquias de santos que cubrían y adornaban dicha estancia. Unas "sillas pequeñas, la una de terciopelo carmesí y las dos de cuero leonado y la otra de negro", cumplían la función del reposo en un espacio dedicado a la oración, el aprendizaje religioso y el rezo.

II, p. 94.

22 TORREMOCha Hernández, M.: "Modelos de espiritualidad barroca 'De la que tomó estado matrimonial", en Burrieza Sánchez, J. (ed.): El alma de las mujeres. Ámbitos de espiritualidad femenina en la modernidad (siglos XVI-XVIII), Valladolid, Ediciones Universidad de Valladolid, 2015, p. 195.

23 Doña Aldonza Floch de Cardona, esposa de don Miguel Ximénez de Urrea, II conde de Aranda, mandaba en sus últimas voluntades en julio de 1532: "que las reliquias que yo tengo en mi oratorio sean dadas a mi señor para que su señoría haga dellas a su voluntad". Testamento y codicilo de Aldonza Floch de Cardona, Épila, 1 de junio y 10 de julio de 1532. AHPZ, CDH, P/4-113-16.

24 Testamento de don Pedro de Urrea y Enríquez, señor del Val de Almonacid. AHPZ, CDH, P/4-113-24.

25 Doña Juana legaba a su hijo primogénito, Pedro, "las Ymagenes y aderezo de mi oratorio". Testamento de Juana Enríquez y Cabrera, condesa de Aranda, viuda de Juan Ximénez de Urrea, III conde de Aranda, Zaragoza, 23 de julio de 1596. AHPZ, CDH, P/4-113-23. 
En ambas estancias abundaban las imágenes y reliquias de santas mujeres, que quizás permiten vincular estos espacios sagrados dentro del hogar con la actividad creadora y el poder de decisión femenino. Puesto que su propietaria, la condesa doña Juana, había tenido una viudedad larga entre 1586 y 1599, en la cual fue responsable principal de la administración del nuevo palacio de los condes. En este sentido destacan los adornos del oratorio pequeño, probablemente espacio personal que había disfrutado como propio doña Juana Enríquez:

Primo un relicario pequeño que está en medio una Sancta Cathalina de Siena Mas un Agnus Grande de la Trinidad

Mas otro de la Resurrection

Mas otro de la Veronica

Mas otro de la Angustia

Mas debaxo desto un retablico de Christo con sant Juan y Nuestra Señora

Mas ocho de la Anunciaçion

Mas un retablo de Sancto Thomas de Aquino y otro de Sancto Domingo

Mas un retablico de la Magdalena

Mas otro de Sancta Cathalina de Sena

Mas una Ymagen de Nuestra Señora y Sant Bernardo

Mas un relicario con un nombre de Jesús en medio

Mas un retablico con tres imágenes la una de Nuesta Señora de la Angustia y la otra de Sancta Cathalina y de Sancta Luzia

Mas un relicario grande con una imagen de Nuestra Señora del Rosario en me$\mathrm{dio}^{26}$.

La religiosidad de la dama puede buscarse, por lo tanto, expuesta en este tipo de cámaras cuyo interior presentaba un reflejo de la devoción particular de la mujer noble, capaz de rodearse de representaciones de aquellas advocaciones a las que se encomendaba de manera personal.

Estos oratorios y capillas ubicados en el interior de las residencias particulares no sólo estaban reservados a las prácticas más cotidianas de la fe, sino que también albergaban celebraciones religiosas de gran importancia en la historia familiar. La intimidad del hogar y el trato de favor obtenido por las familias nobles fomentaba la celebración de sacramentos dentro de la casa. De este modo, importantes ceremonias religiosas, que marcaban los ritmos vitales y eran habitualmente llevadas a cabo en la iglesia parroquial, entraban en el espacio doméstico para ser celebradas. A finales de 1602, don Martín Fernández de Híjar, conde de Galve, contrajo matrimonio con doña Francisca Martínez de Luna "dentro de una quadra del quarto alto y nuevo de las casas de la propia habitación del Exmo. señor don Juan Francisco Cristóbal Fernández de Yxar, duque y señor de Yxar"27, su padre. Poco tiempo después, el 16 de diciembre de 1621, se efectuaba otro desposorio dentro de las casas del conde de Pavías, don Antonio de Urrea y Enríquez, quien en nombre del conde de Valfogona tomaba por esposa a doña Gabriela de Alagón ${ }^{28}$.

Testamento de don Pedro de Urrea y Enríquez, señor del Val de Almonacid. AHPZ, CDH, P/4-113-24.

27 Desposorio del conde de Galve, Martín Fernández de Híjar con Francisca Martínez de Luna, Zaragoza, 26 de diciembre de 1602. AHPNZ, Protocolo 2.949, ff. 1v.-4r.

28 Desposorio de Juan Galcerán de Castro-Pinós, conde de Valfogona, con Gabriela de Alagón. AHPNZ, Protocolo 1.005 . 
En algunas ocasiones este tipo de ceremonias celebradas dentro de las residencias familiares conducen a través de los espacios y biografía de un determinado individuo. Este es el caso de doña Rafaela Palafox Croy d'Havre, quien en 1748, cuando contaba con cuatro años de edad, había recibido el sacramento de la confirmación "en el oratorio de la casa de los Excelentísimos Marqueses de Ariza [sus padres], en la calle Alcalá" de Madrid. Mismo oratorio donde, trece años después, se desposó con don Pedro de Alcántara Silva Fernández de Híjar, IX duque de Híjar, el 16 de julio de $1761^{29}$.

Dichos ejemplos revelan las amplias posibilidades que abría la posición social a las familias nobles, capaces de convertir sus hogares en espacios dignos de las celebraciones sacramentales, gracias en parte a sus conexiones con importantes figuras de la jerarquía eclesiástica. Esta búsqueda de lo privado como espacio religioso se había convertido en un signo de distinción social que ofrecía a los poderosos toda una serie de ventajas en relación a una cotidianeidad guiada por los ritmos y obligaciones marcados por la fe católica. La casa noble podía incluso transformarse para construir en su interior estructuras efímeras que sirviesen como espacios de culto improvisados en momentos de gran necesidad. De este modo, el 12 de julio de 1750, tras el fallecimiento de la duquesa doña María Engracia Abarca de Bolea

[...] sin pérdida de tiempo, se desembarazó de todo adorno y cortinaje la pieza inmediata a la principal de Estrado en que falleció Su Excelencia y se cubrió de tapices verdes y en sitios correspondientes (reservando el vacío que ocupaba la puerta para entrar a dicho estrado) se construyeron quatro altares, adornados con las precisas alhajas que pide la celeridad, y en tales cassos se acostumbra: es a saver: un quadro grande de particular devoción, con moldura para cada uno: una messa altar: frontal: cruz o crucifijo: ara: manteles: candeleros: y en ellos velas amarillas: atril: missal: lavabo: y Evangelio de Sn. Juan: cáliz: vinagreras y los ornamentos necesarios para poder decir missa ${ }^{30}$.

Junto a todas estas manifestaciones íntimas dentro de la casa, la fe también se desarrollaba en espacios públicos y establecimientos religiosos. En ellos, la educación en las creencias, el culto diario y festivo o la vida tras los votos abrían las barreras de la casa o palacio familiar para adentrarse en prácticas religiosas y sociales compartidas que invadían espacios muy diversos. Prácticas que fomentaban la visibilidad pública de los miembros del linaje y, entre ellos, de las mujeres de la casa.

29 “...] cuyo desposorio celebró su eminencia [don Luis Antonio Fernández de Córdoba, cardenal, arzobispo de Toledo] en la calle de Alcalá y casa de habitación de los expresados Señores Marqueses de Ariza, padres de la excelentísima señora contrayente, siendo testigos los excelentísimos señores don Christobal de Portocarrero, conde de Montijo, don Joaquín de Zúñiga, duque de Béjar, ayo de los sermos. señores Príncipe e Infantes, y don Pedro de Alcántara Pimentel, Marqués de Fabara, con otros muchos”. Enlace de don Pedro de Alcántara Fernández de Híjar, IX duque de Híjar y doña Rafaela Palafox, Madrid, 16 de julio de 1761. AHPZ, CDH, P/1128-9.

30 "Razón de quanto se ha executado en el depósito, entierro y honras de la excelentísima señora doña María Engracia Abarca de Bolea, esposa del VIII duque de Híjar, don Joaquín Diego Silva Fernández de Híjar", Zaragoza, 12 al 14 de julio de 1750. AHPZ, CDH, P/1-357-33/1. 


\section{La religiosidad en el exterior. Educación, profesión, culto y patronazgo}

Uno de los acercamientos más tempranos de las mujeres de la nobleza a la religiosidad, en espacios distintos al hogar familiar, venía de la mano de las prácticas educativas. Aunque la primera educación de las niñas privilegiadas solía llevarse a cabo en casa, de la mano de madres y tutores privados, la entrada en el convento desde muy niñas de mujeres nobles planteaba el aprovechamiento de dicha situación para la obtención de una formación adecuada.

Durante la modernidad, la entrega de las jóvenes de la familia quedaba vinculada a centros religiosos de importante relación con el linaje paterno y materno de las niñas, a los que se unían los establecimientos de gran fama en el territorio familiar. Este fue el caso de las dos hijas pequeñas de don Martín Abarca de Bolea, I conde de las Almunias, y de su segunda esposa, doña Ana de Mur que, obligados por las necesidades económicas y la imposibilidad de la reunión de dotes matrimoniales cuantiosas para las menores de sus cuatro hijas, decidieron la entrada en religión de doña Lorenza y doña Ana Francisca. Ambas, desde muy pequeñas, pasaron a formar parte de las comunidades de dos monasterios oscenses, Santa María de Sigena y Santa María de Casbas respectivamente, reputados centros vinculados a las posesiones familiares situadas en las cercanías de la ciudad de Huesca. Allí recibieron una esmerada educación y profesaron como religiosas, además de mostrar durante su vida una destacada producción literaria, mayor en el caso de doña Ana Francisca Abarca de Bolea, ( $\dagger$ circa 1686). Mujer letrada y autora reconocida en su tiempo como miembro del círculo cultural oscense, vivió "desde los tres años en el convento de Casbas y fue allí donde recibió la formación espiritual y la educación propia de una mujer de su época y nivel social"31.

A pesar de las reticencias del Concilio de Trento en relación con las vocaciones forzadas, la costumbre de elegir como futuro para algunas de las niñas de la familia un destino religioso siguió siendo común entre los linajes privilegiados de la modernidad. El ingreso de éstas en el convento a muy tierna edad hacía que su conciencia espiritual y su devoción personal se desarrollasen dentro del espacio religioso en sí mismo. La temprana entrada en religión dirigía la aparición de una fe en la que influía destacadamente el confinamiento en el establecimiento elegido y la actividad en él desarrollada.

Los centros religiosos fueron por tanto, en un primer momento, lugares de retiro y guardería para las niñas, que se iniciaban allí en la imitación de la vida monástica. En ellos, las muchachas adquirían y tomaban como suyas devociones propias de los lugares en los que se criaban, advocaciones que obtenían su fidelidad continuada y mostraban la importancia del espacio de vida en la creación de las devociones particulares. Muchas de estas niñas pasaban de ser internas a novicias sin salir del recinto conventual, ya que las órdenes femeninas se nutrían en gran medida de la cantera del internado.

Procedentes de familias aristocráticas, las mujeres nobles profesas en los conventos femeninos "ocupaban los puestos más importantes del gobierno y administración" 32

${ }_{31}$ Campo Guiral, M. ${ }^{\text {a }}$ A.: Doña Ana Francisca Abarca de Bolea, Zaragoza, DGA, 1993, p. 32.

32 Donahue, D. R.: "Wondrous words: miraculous literacy in the convents of Earl Modern Spain" en CRUZ, A. J. y Hernández, R. (eds.): Women's Literacy in Early Modern Spain and the New World, Aldershot, Ashgate, 2011, p. 107. 
de los establecimientos donde profesaban ${ }^{33}$. Dichas mujeres eran poseedoras de un poder visible dentro del mundo religioso, así como de influencia en los espacios civiles cercanos que se encontraban bajo jurisdicción del convento o monasterio donde habitaban. Las religiosas de la familia obtenían de este modo una importancia clave en la evolución del linaje, que contaba con ellas como apoyo dentro de las comunidades religiosas.

En dichas comunidades, las damas se encontraban amparadas por toda una serie de redes de parentesco e influencia construidas a través de la entrada en el recinto religioso de otras mujeres de su Casa. Sor María de Alagón, hermana del IV conde de Sástago y monja en el convento de Santa Inés de Zaragoza, esperaba en 1603 que se cumpliese la voluntad de su hermano para recibir a su sobrina Catalina y proveerla de una buena educación y posición en el convento ${ }^{34}$. Del mismo modo, sor Teresa del Espíritu Santo, hija del señor de Bureta y monja en el convento de la Concepción de la villa de Épila, recibió allí a finales de la primera mitad del siglo XVII a su hermana pequeña, la futura sor Manuela de la Concepción ${ }^{35}$. Por todo ello, gracias al destino de damas a la vida conventual, sus linajes veían aumentar su influencia relativa a los espacios religiosos no sólo a través de la carrera eclesiástica de los varones de la Casa, sino también por medio de la fuerza ejercida por aquellas mujeres para las que fue elegida una vida en religión.

La realización de los votos variaba en su naturaleza al tratar los casos relacionados con mujeres nobles de mediana o avanzada edad, libres ya de las cargas familiares debido a su viudez y falta de tutela masculina. Capaces de decidir de forma individual su entrada en un convento, muchas mujeres de la nobleza elegían los establecimientos religiosos como espacios "donde resguardarse y continuar sus días de forma honorable, a veces haciéndose acompañar también por sus hijas" ${ }^{36}$. Dichos conventos o monasterios elegidos habían sido en ocasiones fundados por ellas mismas: bien junto a sus esposos, bien por iniciativa personal fruto de su vocación religiosa. De este modo, las mujeres nobles creaban espacios de retiro donde poder cultivar su fe y en los que podían "seguir ejerciendo un papel relevante, de mando y preeminencia, acorde con su posición social" 37 .

En el caso relativo las mujeres de la nobleza pertenecientes a las familias Aranda e Híjar, en las que se centra este estudio, es necesario realizar un breve apunte relativo a la especificidad de una situación característica. Es preciso señalar como esta opción de búsqueda de una capacidad de actuación más amplia dentro del convento fue probablemente innecesaria para ciertas damas nobles, que, debido al origen de sus linaje, se veían en muchos casos amparadas por el derecho aragonés. La lega-

33 Doña Leonor de Híjar, hija del matrimonio formado por el II conde de Belchite, don Juan Fernández de Híjar y Enríquez (†1509) y doña Isabel Ramírez de Arellano († 1521), fue priora del monasterio oscense de Santa María de Sigena entre 1548 y 1555. También, la citada, doña Ana Francisca Abarca de Bolea fue abadesa entre 1672 y 1676 del centro que la acogió de niña.

34 Testamento de Gabriel Blasco de Alagón, IV conde de Sástago, Zaragoza, 21 de noviembre de 1603. AHPNZ, protocolo 2.950, ff. 1.707r.-1723r. Doña Catalina de Alagón (1602- ca.1653), quien finalmente no profesó en el convento por deseo de su madre, era a la vez hija de doña Mariana de Urrea y nieta de los III condes de Aranda, don Juan Ximénez de Urrea (†1586) y doña Juana Enríquez y Cabrera (†1599).

35 Ambas eran hijas de don Lope de Francia y Espés, señor de Bureta, y sobrinas de don Alonso de Francia y Espés, arcediano de Belchite, que las nombra e identifica en su testamento, Zaragoza, 16 de mayo de 1647. Véase AHPZ, CDH, P/1-146-19.

36 Atienza, Á.: Tiempos de conventos. Una historia social de las fundaciones en la España Moderna, Madrid, Marcial Pons, 2008, p. 328.

37 Ibidem, p. 333. 
lidad foral y las negociaciones efectuadas en sus pactos matrimoniales permitían a algunas de estas mujeres beneficiarse del específico derecho de viudedad foral aragonesa. A través del mismo, las damas podían resultar usufructuarias de todas las posesiones de su esposo tras el fallecimiento del mismo, siempre que no volviesen a contraer matrimonio. Esta opción permitía a las damas disfrutar como viudas nobles de unas amplias parcelas de poder, hecho que podía influir en descartar la opción del sacrificio requerido por la toma de los votos religiosos ${ }^{38}$.

Sin embargo, la falta de profesión religiosa no disminuía las prácticas piadosas de las damas pertenecientes a estos grandes linajes de la modernidad. Además de su estrecho vínculo con el mundo religioso en la intimad del hogar, su relación con el mundo de la fe presentaba una destacada vertiente pública, abierta y visible que convertía a la dama en parte de las prácticas tradicionales de la religión católica en los espacios de sociabilidad.

Junto al expresado uso de oratorios y capillas privadas para el desarrollo de los oficios diarios dentro de las casas nobles, las mujeres privilegiadas y sus familias compartían con la comunidad religiosa iglesias y ermitas locales elegidas en relación con su ubicación o su advocación determinada. De este modo, las parroquias locales de los lugares patrimoniales del linaje eran las receptoras de las atenciones de las damas nobles durante los periodos de residencia en aquellas villas que daban nombre a sus títulos; una atención que variaba en sus traslados a la ciudad o a la capital del reino, en las cuales la proximidad era el valor destacado en la elección del espacio de culto.

Como ejemplo puede seguirse el caso de los duques de Híjar, quienes eligieron diferentes espacios públicos de religiosidad acordes a la evolución de su situación familiar a lo largo de la Edad Moderna. La iglesia parroquial de la villa de Híjar, dedicada a Santa María y primer espacio de enterramiento familiar ${ }^{39}$, fue sustituida en importancia -pero nunca relevada- por una fundación ducal en la misma villa, el monasterio de Santa María de los Ángeles. Ambas iglesias fueron siempre lugares muy queridos y respetados por los miembros del linaje, que buscaron su misma advocación en espacios de enterramiento ${ }^{40}$ y regresaron a adorarlas en diversas visitas a su localidad de origen ${ }^{41}$. El traslado de la residencia habitual de los Duques desde el palacio de Híjar a sus casas zaragozanas motivó una nueva relación de la familia con las parroquias más cercanas a su domicilio en la ciudad. De este modo, los Duques, cuya casa se encontraba al norte de la antigua calle Cuchillería, se hallaban unidos a la parroquia de Santiago, hecho que cambió con su traslado a sus nuevas casas del Coso a finales del siglo XVII, momento a partir del que fueron fieles en su compromiso con la iglesia de san Gil. El acercamiento a la corte madrileña y sus nuevas residencias en la misma, principales espacios de su habitación en el siglo

38 Véase "Viudedad foral y viudas aragonesas" en García Herrero, M". C.: Del nacer y del vivir. Fragmentos para una historia de la vida en la Baja Edad Media, Zaragoza, Institución Fernando el Católico, 2005, pp. 155176.

39 En ella mandaron depositar sus restos don Luis Fernández de Híjar, I conde de Belchite, y su esposa doña Guiomar Enríquez de Mendoza en la década de 1510. AHPZ, CDH, P/4-048-01 y P-1 188-14.

40 De este modo don Fadrique de Silva y Portugal, esposo de doña Juana Petronila Silva Fernández de Híjar, VI duquesa, mandaba enterrarse en "el hueco de un altar erigido a Nuestra Señora de los Ángeles que está en la capilla mayor de dicho convento" capuchino de Villarrubia de los Ojos del Guadiana. Fe de muerte de Fadrique de Silva y Portugal, 17 de julio de 1700. AHPZ, CDH, P/1-393-30.

41 "Práctica y ceremonial con que recibieron a los Excelentísimos Señores Duques de Híjar, don Isidro y doña Prudenciana, en dicha su villa, con motivo de haver pasado a visitar el santísimo a la Iglesia Parroquial y dar gracias por su feliz viage", Híjar, 13 de septiembre de 1744. AHPZ, CDH, P/1-263-20. 
XVIII, vincularon a la familia con parroquias de la capital cercanas a sus lugares de residencia ${ }^{42}$.

Junto a este uso compartido de los espacios públicos de religiosidad con los habitantes de sus villas y ciudades de residencia, es necesario destacar la participación de las mujeres de la nobleza en las instituciones colectivas de religiosidad laica. Éstas mostraban orgullosas su pertenencia a diversas cofradías devocionales, las cuales eran exhortadas en el momento del fallecimiento de la dama para participar como miembros activos en el último adiós a la misma. De este modo lo indicaba en sus últimas voluntades la condesa de Aranda, doña Catalina de Híjar y Beaumont $(\dagger 1521)^{43}$, al igual que doña Francisca de Castro-Pinós, quien en 1663 pedía que "en mi [...] entierro se me lleve a la Cofradía del Transfixo y Animas, de que soy Cofradesa" 44 . Esta vinculación con las cofradías tenía como fin facilitar a sus miembros una buena muerte y constituía un paso más en la búsqueda de la salvación individual. Con el objetivo de conseguir dicha salvación, las mujeres de la nobleza se encomendaban a un gran número de figuras santas, elegidas para el rezo individual y la petición por el alma propia y la de los familiares más cercanos.

Aquellos santos a los que las damas dedicaban sus oraciones se encontraban muy ligados al espacio en el que se desarrollaba la vida de cada una de estas mujeres nobles. Por un lado, destacaban las devociones específicas de los cultos territoriales del lugar de residencia y, por otro, las figuras santas que vinculaban a la dama con sus espacios natales o relativos a su familia de sangre. La gran movilidad femenina, dentro de la nobleza española de la Edad Moderna, causada por los enlaces matrimoniales, favorecía el traslado de devociones particulares dentro de la Península y la combinación de veneraciones a través del viaje de las diversas advocaciones. Este culto a los santos no era un hecho privativo de la elite social, sino que se extendía a ella a través de su pertenencia a una determinada comunidad religiosa y era siempre compartido con otros fieles.

De este modo, las mujeres de la nobleza adoptaron cultos a santos protectores de las familias a las que se unían por matrimonio que evidenciaban la relación existente entre las advocaciones preferidas de un linaje y sus espacios patrimoniales. A las devociones más extendidas de las pequeñas villas de origen de las familias nobles - como Nuestra Señora de los Ángeles de Híjar, Nuestra Señora de Rodanas en Épila, el Santo Cristo de Calatorao o Nuestra Señora de la Sierra (Villarroya)-, se unían aquellas veneraciones principales de mayor arraigo, que hacía destacar para las familias de origen aragonés la figura de la Virgen del Pilar de Zaragoza.

Al mismo tiempo, las costumbres religiosas de un linaje se enriquecían con la llegada de miembros externos, en este caso miembros femeninos, que portaban advocaciones propias de su persona y de su Casa. El culto a los santos protectores viajaba y se trasladaba con las damas, y aunque la influencia de la tierra adoptiva y las costumbres en materia religiosa solían ser muy fuertes, siempre quedaba un espacio en la memoria individual reservado a los cultos del propio origen. Dicha idea puede

$\overline{42}$ Entre ellas destacaron la parroquia de Santiago, de san Sebastián o de san Martín, en relación con la situación de los diversos domicilios de los Duques.

43 Sean "llamadas las Cofradías del Transfixo, la del Ángel Custodio, la de San Gregorio e la de las Animas del Purgatorio, de la dicha ciudad de Caragoça de las quales yo soy cofradesa, y los Cofrayres de aquellas hayan de acompañar mi cuerpo a la Yglesia y sepultura". Testamento de Catalina de Híjar y Beaumont, condesa de Aranda, 1519. AHPZ, CDH, P/4-113-15.

44 Testamento de Francisca de Castro-Pinós y Fenollet, esposa de don Juan Francisco Cristóbal Fernández de Híjar, II duque de Híjar, Zaragoza, 3 de octubre de 1663. AHPZ, CDH, P/1-146-10. 
tener como ejemplo, las palabras de la citada duquesa doña Francisca de CastroPinós, que fallecida el 28 de octubre 1663, nombró como su protector a san Esteban, patrón de la casa de Pinós, de su familia y por tanto de su persona. El apego al patrón de su casa, conservado con gran fuerza también al entrar por matrimonio dentro de una nueva familia, planteaba una devoción que se vio plasmada en una hermosa tapicería mandada fabricar por la duquesa en Zaragoza que

era riquísima y de singularísimo valor y estimación y contenía la Historia Milagrosa de la Casa de Pinós, con campo de seda de diferentes colores y grandes realces y relieves de hilo de oro y plata, y que era estimada por lo más singular de España; de calidad que en las funciones públicas, quando la exponían al público, era la admiración de los circunstantes y oyó el testigo [...] decir públicamente que la dicha Sra. Duquesa Da. Francisca, la havia mandado fabricar en su casa y a sus expensas $^{45}$.

Este era también el caso de la condesa de Aranda Luisa María de Padilla (15911646), quien había aceptado con agrado los cultos tradicionales aragoneses, pero a su vez guardaba en sus mandas testamentarias detalles que permiten vincularla con su familia de sangre y sus espacios de juventud. La condesa encargaba que se rezara por su alma en lugares de culto del territorio burgalés, origen de su Casa (de los condes de Santa Gadea), ante el "sancto Christo de la ciudad de Burgos, que está en el convento de sant Agustín [...], en el sancto Christo de la Santissima Trinidad de la misma ciudad [...] (y) en el convento de Nuestra Señora de Fres del Val, de la orden de sant Geronimo"46.

Además, las damas nobles desarrollaron una importante labor de patronazgo vinculada a estas devociones propias y familiares. Por medio de su actividad como patronas, las mujeres de la aristocracia consiguieron llevar a cabo "una expresión de piedad y una realización de sus objetivos espirituales a través de la fundación, construcción y decoración" 47 de establecimientos religiosos. Estas actividades de patronato presentaban una importante muestra pública del prestigio familiar e individual de la dama que, gracias a su posición privilegiada dentro de la élite social, tenía la oportunidad de ejercer como promotora de un patronazgo religioso.

Las posibilidades femeninas de realizar encargos artísticos y fundaciones en centros religiosos durante la modernidad eran menores que las de los varones, debido a las restricciones sociales y legales impuestas a su sexo. Sin embargo, las damas nobles, "desarrollaron estrategias ingeniosas que les permitieron explorar el potencial de las artes como una forma de proclamar su identidad y sus gustos"48. El patronazgo religioso ejercido por las damas de la nobleza tenía características muy variadas, puesto que las pequeñas donaciones femeninas con carácter bastante personal, podían evolucionar hasta convertirse en importantes fundaciones monásticas y obras constructivas reflejo público del poder individual y del linaje de la mujer patrona.

\footnotetext{
45 Noticias de la tapicería del protomártir San Esteban y la Ilma. Casa de Pinós con copia de la información del valor de aquella. AHPZ, CDH, P/3-15-1.

46 Testamento de Luisa María de Padilla, esposa del V conde de Aranda, Antonio Ximénez de Urrea, por Martín Duarte, Épila, 18 de febrero de 1645. AHPZ, CDH, P/1-370-30.

47 LAurence, C. (ed.): Women and art in Early Modern Europe: patrons, collectors and connoisseurs, University Park, Pennsylvania State University Press, 1997, p. 5.

48 Ibidem, p. 6.
} 
Esta actividad poseía en su vertiente más intima el patronazgo femenino vinculado a la entrega de objetos personales, destinados al embellecimiento de las capillas de sus santos predilectos. En dichas acciones quedaba reflejado el gusto individual de las damas nobles, quienes hacían públicas sus devociones particulares, a las que adornaban con sus vestidos y sus joyas. De este modo, doña Beatriz de Alagón, condesa de Belchite, enviaba tras su muerte en 1523, "a los monjes observantes de san Francisco de Híjar, todos mis vestidos y ropas de colores para que hagan con ellos adornos para el monasterio"49.

A su ejemplo se unía, años después, la voluntad de doña Ana de la Cerda y Mendoza, II condesa de Galve, quien destinaba en 1584 gran cantidad de telas y lámparas de metales nobles a las capillas, monasterios y parroquias que contenían sus devociones más apreciadas:

Al monasterio de Nuestra Señora de Atocha, en Madrid, una saya de raso blanco y una lámpara de plata

A Nuestra Señora de la Salceda en el reino de Castilla, una lámpara y un cáliz de plata, un frontal casullas y corporales

A Nuestra Señora del Pilar, dos lámparas, frente escudos y un manto de tela de coro azul y frontales para las capillas de dentro y de fuera y un dosel sobre pilar de damasco azul

Al monasterio de Nuestra Señora del Olivar, [...] un frontal de raso y un crucifijo de plata para el sagrario y mando que le sea devuelto un crucifijo que yo traje cuando estuve allís ${ }^{50}$.

Estas peticiones femeninas, relacionadas con el desarrollo decorativo de los espacios religiosos, constituían una de las ramas destacadas dentro de las acciones de patronazgo impulsadas por las mujeres de la nobleza. Para analizar dichas acciones, es necesario prestar especial atención al estado civil de las damas nobles cuándo realizaban una fundación o un encargo.

La presencia o ausencia del esposo constituía un factor fundamental en relación con las actividades de la mujer noble como "patrona", ya que era el cabeza de familia el encargado de administrar el patrimonio familiar. Sin embargo, las damas de la nobleza utilizaron sus bienes propios -heredados, asignados o adquiridos por ellas para llevar a cabo un patronazgo a título personal. De este modo, las mujeres casadas también ejercieron como patronas individuales en vida de sus esposos, mostrando un tipo de patronazgo personal femenino no muy corriente y cuyos ejemplos aparecen salteados en la documentación.

A los dos casos anteriores, de doña Beatriz y doña Ana, cuyos encargos fueron realizados durante el matrimonio; debe unirse el de doña Aldonza Floch de Cardona (†1532), esposa de don Miguel Ximénez de Urrea (†1546), II conde de Aranda, quien destinaba "todas las tablas e ymagines de mi oratorio, para que el Conde mi señor juntamente con el padre Prior y con el padre Predicador, hagan dos retablos" 51 . Ya en el siglo XVIII encontramos otro ejemplo, el de doña María Antonia Francisca

Testamento de Beatriz de Alagón, esposa de Luis Fernández de Hijar, III conde de Belchite, Zaragoza, 22 de diciembre de 1523. AHPZ, CDH. P/1-363-8.

50 Testamento de Ana de la Cerda y Mendoza, II condesa de Galve, esposa de Juan Francisco Cristóbal Fernández de Híjar, II duque de Híjar, Zaragoza, 28 de septiembre de 1579. AHPZ, CDH, P/4-95-1.

51 Testamento de Aldonza Floch de Cardona, Épila, 1 de junio de 1532. AHPZ, CDH, P/4-113-16. 
Ximénez de Urrea, esposa del conde de Peralada, don Guillem de Rocafull (†1728), quien testaba en 1721 dejando

Para adorno de la capilla del señor San Antonio de Padua, existente en la Yglesia del Convento de mi Seráfico Padre San Francisco de esta ciudad, los quatro Reposteros, que sabe El Conde, mi Tío y Esposo, tengo destinados para este fin ${ }^{52}$.

Debido a las notables diferencias entre las posibilidades de actuación que ofrecía el conjunto del patrimonio familiar frente a los bienes de la dama, el patronazgo femenino ejercido dentro del matrimonio de forma individual tenía menor capacidad en sus encargos. Éstos solían nutrirse de elementos personales que se transformaban en materiales de adorno para cumplir una tarea decorativa en aquellos espacios a los que iban dedicados o en la fabricación de piezas no excesivamente costosas.

Durante el matrimonio, las mujeres nobles también llevaron a cabo en muchas ocasiones actividades de patronazgo asociadas con sus maridos. Este patronazgo compartido otorgaba al matrimonio una visibilidad pública que jugaba un papel de gran importancia en las tareas de promoción y engrandecimiento del linaje. Por medio de las fundaciones eclesiásticas, la pareja conseguía establecer un vínculo con espacios destacados dentro de los establecimientos religiosos -capillas mayores, capillas familiares, altares-, así como con lugares patrimoniales cuyos habitantes se beneficiaban y observaban con admiración las fundaciones realizadas por los titulares de la Casa noble. Dicho caso fue el que unió a don Antonio Ximénez de Urrea, $\mathrm{V}$ conde de Aranda, con su esposa doña Luisa. Juntos fundaron el año de 1621 en Épila, principal villa del linaje Aranda, el convento de Nuestra Señora de la Concepción de monjas franciscanas concepcionistas ${ }^{53}$. Del mismo modo, doña Francisca de Moncada ( $\uparrow 1645)$, había compartido con su esposo responsabilidades sobre el funcionamiento de la capilla mayor del "convento de san Agustín de la presente ciudad [de Zaragoza] de donde soy patrona", decía ${ }^{54}$. Este caso lleva a destacar como, tras la muerte de sus cónyuges, las mujeres nobles no perdían la titularidad de los patronazgos ejercidos junto a ellos. Las damas seguían siendo las principales responsables de la conservación de dichos espacios religiosos, vinculando su actividad al desarrollo del prestigio del linaje y nombrándose a sí mismas como "patronas".

Esta nueva etapa vital, en la que la viudedad identificaba y caracterizaba las actividades de las damas nobles, otorgaba a las mismas una mayor capacidad de decisión y actuación, ya cesada la tutela masculina imperante durante el matrimonio. Era entonces cuando las mujeres privilegiadas tenían la posibilidad de administrar sus ingresos y una mayor libertad en la elección de sus encargos y destinatarios de sus fundaciones. En este periodo puede observarse una variedad más amplia de comisionados que muestra la voluntad de las patronas. Dicha voluntad no se reducía únicamente a la actividad ornamental de espacios religiosos, anteriormente vinculada al patronazgo femenino individual durante el matrimonio; sino que mostraba una

52 Testamento de María Antonia Ximénez de Urrea. Zaragoza, 6 de mayo de 1716. AHPNZ, Protocolo 4.853, ff. 247r.-251v.

53 Dicha fundación, fruto de un patronazgo compartido, dejaba ver a la vez la influencia ejercida por la dama en la misma. La fuerza de opinión de doña Luisa se hallaba presente en la elección de la entrega del convento a una comunidad religiosa femenina y en la figura santa a quien iba a dedicarse el cenobio: la Virgen de la Concepción, principal figura devocional de la condesa.

54 Testamento de Francisca de Moncada, esposa de Antonio de Urrea y Enríquez, marqués de la Val de Almonacid, Zaragoza, 1 de julio de 1645. AHPZ, CDH, P/4-113-27. 
actividad de patrocinio que unía al adorno la fundación y edificación de establecimientos, así como la creación de elementos específicos destinados a los mismos. Al mandato de 1519, en el que doña Guiomar Enríquez y Mendoza, ordenaba hacer "un retablo para la iglesia mayor de Híjar, de precio 2.000 sueldos" ${ }^{55}$; se unieron la ayuda a la construcción del colegio franciscano de Belchite, encargada por doña Hipólita Fernández de Heredia en $1565^{56}$, o las actuaciones realizadas por doña Juana de Toledo y Osorio en el monasterio de san Francisco de Zaragoza en 1571. Esta última dama obtuvo del capitulo de dicho monasterio el permiso para "romper por medio las dichas gradas del altar mayor [...] e hacer solo lo que convenga al beneficio de dicha capilla, anexuras, derechos y pertenencias della, al arbitrio, parecer y voluntad de su Señoría"s7.

Los deseos personales de las damas guiaban este patronazgo y, además, vinculaban su actividad como patronas con los espacios propios del linaje y con aquellos establecimientos religiosos en los que tradicionalmente se había llevado a cabo un patrocinio familiar. De este modo, ya en la segunda mitad del siglo XVII, doña Francisca de Castro-Pinós destinaba su actividad a la edificación de la iglesia del mencionado convento de san Agustín de Belchite ${ }^{58}$. Sin embargo, la personalidad de las damas unía a estos comisionados otros patrocinios vinculados a su propia individualidad. La citada doña Francisca de Moncada, añadía así a su mencionada proximidad con el convento de san Agustín de Zaragoza, fruto de sus relaciones familiares, ciertas cantidades de sus bienes reservadas a un patronazgo más personal que fueron dedicadas a

los Padres Carmelitas Descalzos de la ciudad de Caragoza, que ha muchos años que acuden al consuelo y gobierno de mi conciencia [...] para una fundación y convento de Religiosos de la misma orden de Carmelitas Descalzos, dentro del Reyno de Aragon, en la ciudad, villa, lugar o puesto y de la manera que parezca al padre provincial que es o por tiempo fuere de dicha provincia, con tal que sea aragones y no de otra suerte ${ }^{59}$.

A aquellos comisionados propios que mostraban el agradecimiento a través del patrocinio, deben unirse también los encargos de las damas privilegiadas que no sólo planteaban desde el punto inicial la creación de nuevos espacios religiosos u obras artísticas, sino que trabajaban en la remodelación de los centros de especial aprecio por la comunidad de fieles a la que pertenecían:

En el monte que llaman el Zeparuelo, distante dos leguas de la villa de Híjar, [la duquesa doña Prudenciana] ha hecho reedificar un oratorio y capilla que estaba

\footnotetext{
55 Testamento de Guiomar Enríquez de Mendoza, viuda de don Luis Fernández de Híjar I conde de Belchite. 20 de marzo de 1519. AHPZ, CDH, P/1-118-14.

56 Testamento de Hipólita Fernández de Heredia, viuda de don Luis Fernández de Híjar y Ramírez de Arellano, III conde de Belchite, Zaragoza, 30 de julio de 1565. AHPZ, CDH, P/4-48-14.

57 Permiso del capítulo y convento de san Francisco de Zaragoza a doña Juana de Toledo y Osorio, nuera del II conde de Aranda, don Miguel Ximénez de Urrea, para reedificar la capilla mayor de dicho convento, Zaragoza, 11 de junio de 1571. AHPNZ, Protocolo 4.377, ff. 129r.-132r.

58 Testamento de Francisca de Castro-Pinós y Fenollet, viuda de don Juan Francisco Cristóbal Fernández de Híjar, II duque de Híjar, Zaragoza, 3 de octubre de 1663. AHPZ, CDH, P/1-146-10.

59 Codicilo de Francisca de Moncada. por Juan Francisco Ibáñez, Zaragoza, 9 de octubre de 1645. AHPNZ, protocolo 1.008, ff. 1.019r.-1.024r.
} 
arruinada, para que, celebrándose en ella el Sto. Sacrificio de la Missa, puedan tener el consuelo que en otro tiempo experimentaron los labradores ${ }^{60}$.

Por medio de estos ejemplos, puede plantearse tal como describe Cynthia Laurence que "los encargos y donaciones de arte y arquitectura religiosa resultaron ser uno de los contextos y estrategias más importantes de la participación femenina en la vida cultural y espiritual de la Edad Moderna" ${ }^{61}$. Una actividad que se describe a través del "patronazgo externo" y que expresa una "piedad pública" y un poder femenino que otorgó a las damas privilegiadas la posibilidad de hacerse visibles en un mundo de hombres.

\section{Conclusiones}

La religiosidad femenina a lo largo de la Edad Moderna puede conocerse también por medio del estudio de los espacios cotidianos relacionados con el mundo de la fe. Privados o públicos los distintos lugares de devoción tenían una clara influencia en la elección de las advocaciones particulares de las damas. La vinculación de la mujer noble con aquellas figuras santas destinatarias de sus oraciones y plegarias quedaba configurada en su educación y en el desarrollo de su vida. Pervivencias y nuevas adopciones hacían de las veneraciones particulares un mosaico en que se entremezclaban los deseos propios, las tradiciones familiares y los cultos territoriales.

Las mujeres de la nobleza fueron responsables en la creación, ornamentación y mantenimiento de muchas de estas estancias y centros religiosos dentro y fuera de sus hogares. En ellos expresaron sus intereses y colocaron estampas, lienzos y figuras cuyas descripciones guían a través de sus devociones más personales. Tan variados como las veneraciones debieron ser los deseos de las damas mostrados por los detalles materiales de una religiosidad personal siempre inscrita dentro de unos espacios determinados. Las damas eligieron y construyeron, desarrollaron su fe a la vista de todos y compartieron espacios con una comunidad religiosa que sin duda pudo apreciar su importancia. Aquellas mujeres no se limitaron a vivir la religión únicamente tras los muros de sus casas. Alumnas y maestras, fieles devotas, vivieron la religión desde su posición privilegiada y aprovecharon la oportunidad que ésta les brindaba para honrar sus espacios de culto predilectos. De este modo, gracias al análisis de los distintos ambientes religiosos presentes en la vida de las mujeres nobles de la modernidad y de los elementos que los configuraban, es posible acercarse a la religiosidad de las damas privilegiadas a través de sus espacios cotidianos de devoción.

\footnotetext{
60 Comisión dada por el arzobispo de Zaragoza para que el Vicario de la villa de Híjar visitase la ermita de san Antonio de Padua que se había reedificado por la Duquesa de Hijar. 30 de mayo de 1752. AHPZ, CDH, P/1-26321.

${ }_{61}$ Laurence, op. cit, (nota 47), p. 16.
} 